\title{
Regulating Concessions of Toll Motorways: An Empirical Study on Fixed vs. Variable Term Contracts.* $^{*}$
}

\author{
Daniel Albalate \& Germà Bel. \\ Universitat de Barcelona, Departament de Política Econòmica i Estructura \\ Econòmica Mundial (ppre-IREA). Av. Diagonal 690, 08034 Barcelona \\ (Spain). Phone: +34 93 4021946. Fax: +34 93 4024573. Emails: \\ albalate@ub.edu; gbel@ub.edu.Webpage: www.germabel.cat.
}

\begin{abstract}
:
Recent theoretical developments on concession contracts for long term infrastructure projects under uncertain demand show the benefits of allowing for flexible term contracts rather than fixing a rigid term. This study presents a simulation to compare both alternatives by using real data from the oldest Spanish toll motorway. For this purpose, we analyze how well the flexible term would have performed instead of the fixed length actually established. Our results show a huge reduction of the term of concession that would have dramatically decreased the firm's benefits and the user's overpayment due to the internalization of an unexpected traffic increase.
\end{abstract}

Keywords: Toll motorways; privatization; concessions; regulation.

JEL codes: H54; L33; L43 ; L92.

* The Spanish Ministry of Education and Science (SEJ2006-04985) has financially supported our research. 


\section{INTRODUCTION.}

The private sector's participation in infrastructure funding and management is growing around the world. This increase, that takes especial relevance in the case of toll motorways, justifies a new role for government regulation. Albalate, Bel and Fageda (2007) recently noted that as the size of the private sector increases in the toll motorway sector in Europe, the more detailed and specific its regulation becomes. ${ }^{1}$ Privatization of toll motorways is an emerging market in the US too. The concession of Chicago Skyway in 2005 and Indiana Toll Road in 2006 have been the first privatization operations, within a more general trend that includes prospects for privatization of tollways in New Jersey, as well as Build-Operate-and-Transfer (BOT) concessions in Texas. Therefore, the described wave of privatization is accompanied by a renewed interest on the way the public sector regulates, and the redistributive effects that can arise by the fact of giving the right to exploit a natural monopoly explain this interest. ${ }^{2}$

The recent history of motorway privatization does not provide a systematic rationale to support the private participation in this sector without further discussion. The cases of Mexico, Argentina, Colombia, Thailand and Malaysia, even the Spanish and French experiences in the second half of the seventies, are good examples of this failure and are well documented in Gómez-Ibáñez and Meyer (1993), Fishbein and Babbar (1996), Ruster (1997), Bel (1999), Engel, Fischer and Galetovic (2003) and Bel and Fageda (2005). Perverse renegotiations, huge public financial guarantees or massive public resources devoted to cover private losses, the construction of white elephants, and general firm breakdowns are just some of the consequences associated with the introduction of private funding in those experiences. ${ }^{3}$

\footnotetext{
1 Albalate, Bel and Fageda (2007) argue that regulation and public ownership are partial substitutes in the European toll motorway industry.

${ }^{2}$ See Bel and Foote (2007) for an analysis of the case of Chicago Skyway and Indiana Toll Road.

3 A white elephant is an investment project with negative social surplus (Robinson and Torvik, 2005)
} 
Fortunately, the influential works of Engel, Fischer and Galetovic (1997, 2001) brought some light to the sources of these problems that arised in concessions of infrastructure with huge sunk costs and uncertain demands. Since the need for huge sunk investments is significant in transport infrastructure projects, and the evolution of traffic demands cannot be foreseen for such a long period of time as it is necessary to cover initial investments, it makes sense to expect problems when the traffic received is actually lower than expected or on the contrary, when there is an unexpected increase.

Therefore, it is not surprising that Guasch (2004) finds high percentages of renegotiated contracts in sectors like Transportation (54.7\%) and Water and Sanitation (74.4\%) due to their similar characteristics - huge sunk investments, long concession terms and unexpected future demands.$-{ }^{4}$ These renegotiations are caused by the pressure put by the private sector when the problem relies on low traffics and by governments when unexpected increases of traffic generates enormous benefits that threat its political acceptance. Avoiding these renegotiations becomes a challenge for policy makers. Since it is actually a relevant public policy problem, its study represents an issue of great interest for the public economy. For all these reasons, the improvement of the regulatory framework and the right assignment of risks and incentives must be taken with especial attention and accuracy, in particular when the private sector takes part.

Auctions, that serve as an instrument to introduce competition for the market in sectors where it is not possible to have competition in the market, are usually based on awarding concession contracts in which the length is established and known from the beginning. This term is usually set only on the expected evolution of traffic and on the financial factors exposed by the firm. In fact, it is the main responsible for the traffic risk

\footnotetext{
${ }^{4}$ Guasch (2004) considers more than 1.000 concession contracts in Latin America in order to get solid lessons for future policy makers. The total incidence of renegotiation he finds is $30 \%$, much lower than the incidence rate found in transportation and water and sanitation.
} 
assumed by the concessionaire and generally covered by state guarantees, renegotiations and transfers.

To overcome the pitfalls above mentioned and to provide a useful tool for policy makers, Engel, Fischer and Galetovic (1997, 2001) and De Rus and Nombela (2004), proposed two flexible term mechanisms based on a guaranteed present revenue that makes irrelevant the length of concession for the companies holding the right to exploit the road. The length of concession now gets adjusted depending on traffic evolution and tariffs applied to users, making possible to accommodate unexpected events and to design price schemes that satisfy assignative efficiency criterias to regulate traffic demands when changing capacities becomes impossible in the short run. In addition, the use of flexible term contracts reduces the incidence of renegotiation, allowing for a more transparent and predictable scenario and smoothing the risk assumed by governments and firms.

In spite of their academic success, flexible term methods have never enjoyed a significant support in practice. Furthermore, the motorways that implemented this regulatory strategy were quite recently built and it is not possible to reasonably compare both mechanisms. For this reason, we use real data reported by two of the oldest toll motorways in Spain, ruled by a private firm under a traditional build-operate-and-transfer (BOT) concession, to check how well flexible term contracts would have performed in those cases.

The current study is organized as follows. In the next section the problems of fixed term contracts are exposed and the models proposed to solve the concerns above mentioned are introduced. In the third section we describe the simulation strategy that we follow in order to compare both mechanisms in the case of two real Spanish toll motorways while in the fourth we provide our main results. Finally we state some concluding remarks in the last section. 


\section{FIXED VS. VARIABLE TERM MECHANISMS.}

Engel, Fischer and Galetovic (1997, 2001, 2002, 2003) argue that all the problems associated with private toll road experiences were mostly related to the Build-Operate-andTransfer (BOT) contracts agreed and awarded in traditional auctions based on the rules of minimum toll, subsidy or term offer. All these cases imply the establishment of a fixed term of concession that serves to explain most of the problems that arised in the countries that used this policy to obtain private resources to fund motorway programs.

When a company decides to participate in a toll motorway concession auction it takes into account several factors. Demand forecasts, user's willingness to pay and building and operating costs are the most important ones. For this reason the present value expected by the firm when it studies the offer it is willing to submit in the tender is the following one:

$$
P V=\sum_{t=k}^{T} P_{t} Q_{t} \frac{1}{(1+r)^{t}}-\sum_{t=1}^{t=k} B c_{t} \frac{1}{(1+r)^{t}}-\sum_{t=k}^{T}\left[M c_{t}(q)+A c_{t}(q)\right] \frac{1}{(1+r)^{t}}-\sum_{t=1}^{T} F c_{t} \frac{1}{(1+r)^{t}}
$$

Where $\boldsymbol{P}$ is the average toll, $\boldsymbol{Q}$ the expected traffic and $r$ the discounting rate. $B c$ represents the building costs, $\boldsymbol{C} \boldsymbol{m}$ the maintenance costs and $\boldsymbol{C} \boldsymbol{a}$ the administrative costs. The first, only takes importance in the years before the opening, while the rest depends on the vehicles actually received and appear once the road is opened. Finally, $\boldsymbol{F} \boldsymbol{c}$ is the financial cost of this investment and can appear during the whole concession period depending on the financial policy followed. Thus, $\boldsymbol{K}$ represents the first year of operation while $T$ is the last year of concession. Then, $t=1,2, \ldots, k-1, k, k+1, \ldots, T$. As equation (1) shows, when $\mathbf{t}<\mathbf{k}$ the concessionaire is building the road and does not receive toll revenues. 
Once the decision on toll or term offer based on the present value above described is taken, it is easy to see that if the traffic actually received is significantly lower than expected, then the company could suffer financial troubles. This circumstance is known in the auction literature as the winner's curse. ${ }^{5}$ On the contrary, when the demand received by the road is soundly higher, then the firm's profits will increase so much that if it continues during a long period of time, then the political acceptance of the regulatory framework by the public might decrease and affect the levels of popularity enjoyed by the government.

Up to now, it would seem that the traffic risk is assumed by the winning company. However, the literature shows that private firms usually forced favourable renegotiations when the adverse scenario appeared. These renegotiations have been the general rule around as Guasch (2004) and Estache and de Rus (2000) explain, and they have caused toll increases, extended terms, state guarantees, and massive transfers to private companies (Gómez-Ibáñez and Meyer, 1993; Ruster, 1997; Bel, 1999)

Furthermore, De Rus, Romero and Trujillo (2000) warn that this uncertainty associated with the toll motorway business can also be transferred to the users if the company claims for higher tolls or longer terms when they decide what offer to submit in the awarding auction. As a consequence, the uncertainty is finally assumed by the users through higher tolls or longer terms when this effect is present or when the renegotiation implies the same changes in the initial contract. Finally, since we cannot forget that road users are also tax payers, they are also assuming this risk when the state decides to transfer resources or when they give favourable guarantees.

In the same direction, companies can act strategically in the auction. This means that companies which are used to renegotiate or feel themselves very close to the government, can submit too optimistic offers in order to win and force a renegotiation later. In addition, they can be interested in the concession of white elephants if they are

\footnotetext{
${ }^{5}$ The concept of the Winner's Course was first discussed in Capen, Clapp and Campbell (1971).
} 
convinced that the state will rescue the firm once it suffers financial troubles. This fact imply that the winner of the auction is not always the most efficient and Engel, Fischer and Galetovic (1997) and Nombela and De Rus (2004) assert that this is one of the worst outcomes of fixed term concessions.

The last problem is the rigidity of tolls. Prices, in the case of motorways, are usually only thought to satisfy financial needs. Under this fixed term scheme it is not possible to vary the toll in order to accommodate it to the traffic received without affecting the financial results of the firm. Unfortunately, this constraint makes impossible to fulfil the function the toll should have as a price that regulates traffic demands in order to fight congestion and overcapacity when infrastructure enlargements are not possible in the short run. The classic works of Pigou (1920), Walters (1968) and Vickrey (1969) and other recent studies like Nakamura and Kockelman (2002), De Palma, Kilani and Lindsey (2005) or Burris (2006), prove the necessity of having variable toll schemes in order to fulfil this function.

\subsection{Least Present V alue of Revenue (LPVR).}

To solve all the pitfalls generated by the establishment of fixed terms, Engel, Fischer and Galetovic (1997, 2001) propose a mechanism based on variable term concession contracts called the "Least Present Value of Revenues". In this mechanism the concessionaire obtains the right to receive toll revenues until a total accumulated discounted sum is reached. Once it happens, the concession finishes and the motorway is transferred. Thus, it is not possible to know how many years the concession will last because it definitely depends on the real traffic it receives and the toll setting applied.

Furthermore, the theoretical outcome developed by Engel, Fischer and Galetovic (1997) is that in a competitive auction the winner offers a Present Value of Revenues (PVR) close to the building costs. However, it makes sense to expect the addition of a 
profit margin above this level in practice. Adding up all these elements we find that the PVR awarded is computed in the following form:

$$
\begin{gathered}
P V R=I(1+\mu)=\sum_{t=k}^{T i} \frac{P Q_{i}}{(1+r)^{t}} \\
I=\sum_{t=1}^{t=k} B c \frac{1}{(1+r)^{t}} \\
\mathrm{~T}=\mathrm{f}(\mathrm{I}, \mathrm{P}, \mathrm{Q}, \mu, \mathrm{r})
\end{gathered}
$$

where $\boldsymbol{I}$ denotes the investment undertaken in order to construct the road during the building period; $\mu \in[0,1]$ is the profit margin over the total costs and the rest of variables denote the same they did in equation (1). Thus, the more competitive is the tender, the lower must be $\mu$.

It is straightforward that, ceteris paribus, as higher the traffic demand is, the shorter the time of concession becomes. This is so because the PVR awarded is faster achieved. In the same way, when the motorway receives lower traffic than expected, the traffic risk is mitigated thanks to this mechanism and the term is automatically extended until the firm obtains the PVR awarded.

Therefore, the LPVR mitigates the traffic risk and rescue firm losses while at the same time do not allow the obtention of extraordinary profits caused by excessive user payments. ${ }^{6}$ Moreover, this system based on variable terms allows the implementation of pricing schemes thought to obtain the optimal use of the road because price changes are compensated by extending or reducing the term (De Rus and Romero, 2004). Therefore,

\footnotetext{
${ }^{6}$ LVPR methods also present some caveats. Tirole (1997) discusses some of them. In particular he points out that under this scheme the concessionaire does not have incentives to promote demand increases. Therefore, as it is discussed in Engel, Fischer and Galetovic (2002), the mechanism is only recommended in those sectors in which demand does not respond to the actions of the concessionaire (bridges, tunnels, water reservoirs or roads).
} 
the double function of prices is achieved - financing the infrastructure and regulating traffic demands under efficiency criteria-.

\subsection{Least Present V alue of Net Revenue (LPVNR).}

De Rus and Nombela (2004) noted that only in the limit case when the operational costs are 0 the traffic risk is fully eliminated with LVPR models. The reason comes from the fact that companies also estimate future demands and condition its offers to them because the operational costs affect the project's total cost. The longer is the term, the bigger are the operational costs incurred and therefore, the total costs that must be covered.

To overcome this problem, they proposed another variable term mechanism based on a bidimensional bid that takes into account not only the PVR demanded, but also the operational costs that will be incurred. Again, the concession is awarded to the concessionaire that demands the lower PVR but this time will last until a determined level of net discounted income is achieved. For that reason, it is necessary to make sure that the concessionaire will receive compensation according to the operational costs declared. This method receives the name of the "Least Present Value of Net Revenue".

Therefore, the PVNR awarded now introduces the operational costs $(\boldsymbol{O} \boldsymbol{c})$ and follows the next formulation:

$$
\begin{gathered}
P V N R=I(1+\mu)=\sum_{t=k}^{T}\left[P_{t} Q_{t}-O c_{t}(q)\right] \frac{1}{(1+r)^{t}} \\
I(1+\mu)=\sum_{t=1}^{t=k} B c \frac{1}{(1+r)^{t}} \\
\mathrm{~T}=\mathrm{f}(\mathrm{I}, \mathrm{P}, \mathrm{Q}, \mu, \mathrm{Oc}, \mathrm{r})
\end{gathered}
$$


Again, the term of concession is automatically determined by the traffic received and the toll scheme established. However, in this case, the concessionaire will spend more years in achieving the level of PVR awarded because the operational costs are now substracted from the toll revenue collected.

In fact, what both mechanisms seek is the flexibility of one of the three elements that conforms the concession in order to adjust unexpected events: prices, terms and rules. If none of these factors allows for some flexibility, renegotiations are almost inevitable in sectors with sunk investments and future unexpected demands. On the contrary, when there is some flexibility at least in one of them, the system can be adjusted through this variable mitigating the risk incurred by governments and firms and reducing the incidence of renegotiations. Since the rules are the most complex, opened and therefore, the weakest element of this triangle in practice (figure 1), it is worthier to liberate prices or terms as both mechanisms do.

\section{$<<$ Insert Figure 1 about here $>>$}

\section{SIMULATION STRATEGY.}

Although the recent academic works just described support the implementation of variable term mechanisms of concession because they eliminate traffic risk and assure the most efficient winner, these have enjoyed little impact in practice. In Europe, we can find only two experiences with variable term concession contracts: the 'Second Severn' Crossing in Britain, and the Portuguese bridge 'Lusoponte'. In both cases, the term is endogenously determined but only in the British case the target variable is the total revenue accumulated. ${ }^{7}$ However, as far as we know, only in Chile there is a well documented experience based on

\footnotetext{
${ }^{7}$ In the case of "Lusoponte" the target variable is the accumulated traffic that the bridge receives and a case study on this experience is documented in Lemus et al. (2004). The Second Severn Crossing Experience can be consulted in Foice (1998).
} 
the LPVR approach for the toll motorway Santiago-Valparaíso and a suburban access to the city of Santiago (Gómez-Lobo and Hinojosa, 2000). ${ }^{8}$ For this case, Vasallo (2006) finds that implementing LVPR methods mitigated traffic risks and reduced renegotiation expectations during the economic recession suffered in the late nineties in Chile.

In front of the scarce experiences above mentioned and the short period of operation in the case of the chilenian roads - The "Santiago-Valparaíso" motorway and the suburban access "Acceso Nororiente a Santiago" were awarded in 1998 and 2003 respectively- it is very difficult to compare fixed term and variable term mechanisms in practice.

Nevertheless, we can use the real information on historic European toll motorways in order to compare the fixed term performance with a contra factual based on the LVRP and LVPNR models. This strategy allows for a long period of time that serves to check the most important differences on the outcome of both mechanisms.

The toll motorways chosen are the routes Montgat-Mataró and Barcelona-La Jonquera which were awarded in 1967 for a fixed period of 37 years to ACESA and represent the oldest motorways granted to the private sector in Spain. These concessions that followed a BOT contract with several favourable guarantees for the concessionaire, as it is explained in Gómez-Ibáñez and Meyer (1993), Puncel (1996), Bel (1999) and Bel and Fageda (2005), were supposed to finish at the beginning of the XXI century. However, they are still in operation thanks to several renegotiations that caused term extension until 2021 in both cases. These extensions were undertaken after a period of negotiation between the government and ACESA. In 1990, the renegotiation of the Montgat-Mataró motorway ended with a significant toll cut and the enlargement of the motorway until Palafolls (32 $\mathrm{km}$.). Regarding the case of the Barcelona-La Jonquera, its renegotiation arrived in 1998 in

\footnotetext{
8 In 1998 the government awarded a PVR of 381 US\$ for the building and operation of the toll motorway Santiago-Valparaíso. However, the government set a maximum term of 25 years.
} 
a general process of renegotiation undertaken by the government that affected several concessions and pursued selective toll cuts that were compensated not only with the length extension, but also with transfers from the budget. ${ }^{9}$

Since we have available the financial information disagreggated by route of ACESA for the period 1967-2000, it is possible to construct the contra factual history using this data, in particular, revenues, accumulated investment and operational costs, in order to compute the outcome in terms of years of concession under a variable term scheme like LVPR or LVPNR. Automatically this strategy allows to roughly compute the economic impact on user's welfare and the concessionaire's financial results under this flexible framework instead of the fixed term concession contract actually implemented.

We assume that the private firm was able to predict all the necessary investment required in the road under concession at the moment of the granting process (1967) and therefore, we can compute the PVR or PVNR of 1967 required to cover these costs by ACESA. Once computed this PVR we must accumulate the present value of toll revenues and compute the year in which the firm obtains this PVR. From that year on, the more revenues are collected, the more profit margin is obtaining the concessionaire.

The PVR is computed using the following formula and the year in which the concession terminates is determined when this PVR is bigger than the accumulated investment:

$$
\operatorname{PVR}_{\mathrm{i}}=\sum_{t=1}^{T i} \frac{R_{i t}}{(1+r)^{t}}=I_{i}
$$

where $\boldsymbol{R}$ is the toll revenue obtained by ACESA in each route $\boldsymbol{i}$ and each year $\boldsymbol{t}$. $\boldsymbol{I}$ is the total accumulated investment - this variable includes expropriations, studies and projects, assurances and general costs and finally, financial and building costs. The discounting rate used in this simulation (r) is the Spanish historic discounting rate obtained from the work

\footnotetext{
${ }^{9}$ For a deeper understanding of the nature of these renegotiations see Bel (1999).
} 
by Puncel (1996) for the period 1974-1992; this discount rate is 5\%. However we are going to compute the same using different discounting rates to show the stability of our results.

Unfortunately the operational costs are not available for each route but they are reported for all ACESA concessions during the whole period of concession. These costs are usually close to the $20 \%$ of total toll revenues and this is the percentage that we substract when we compute the term of concession provided by LPVNR mechanism:

$$
\operatorname{PVNR}_{\mathrm{i}}=\sum_{t=1}^{T} \frac{R_{i t}-\left(0.2 R_{i t}\right)}{(1+r)^{t}}=I_{i}
$$

\section{RESULTS.}

Applying these formulas to data we find that the implementation of flexible term concession contracts would have reduced the term of concession in the routes MontgatMataró and Barcelona-La Jonquera given the traffic received and the tolls established during the period of concession studied. For both routes the term of concession would have finished in the late eighties and early nineties even allowing for a reasonable private margin over the accumulated investments. The reader can find a summary of the concession lengths determined by variable term models in table 1 compared to the fixed term of 37 years established by the authorities in 1967.

\section{$<<$ Insert Table 1 about here $>>$}

In fact, as we show in table 2, the PVR would have exceeded the accumulated investment undertaken in the Montgat-Mataró motorway in 1987 and the PVNR would have reached it in 1988. This means, that the PVR and PVNR obtained by ACESA since those years would have fed the profit margin of the company until the end of its concession. In the case of the Barcelona-La Jonquera motorway, we find in table 3 that the 
PVR and the PVNR would have exceeded the accumulated investment in 1988 and 1990, respectively. These results aforementioned are based on the use of a $5 \%$ discounting rate. However, as it is shown in the same tables, the use of different discounting rates, in particular $4 \%$ and $6 \%$, reports similar results.

\section{$<<$ Insert Tables 2-3 about here $>>$}

In any case, the length determined by flexible term methods would have been soundly far from the fixed term of concession established in 1967 if we take into account that our result reports a term of concession between 19 and 23 years for the MontgatMataró motorway and between 20 and 25 years for the Barcelona-La Jonquera route. In both cases the term varies depending on the discounting rate used and the model applied (PVR or PVNR). Thus, there is a substantial difference between these terms determined by PVR and PVNR mechanisms and the 37 years of concession established in 1967.

In figures 2 and 3 we graphically show this comparison. Although it is not fair to compare the terms derived from our analysis with the ones renegotiated - it is not the aim of this research to study and evaluate their conditions and characteristics - it is also true that both were undertaken after those years in which the PVR and the PVNR would have exceeded the accumulated investments. In fact, we found that the renegotiation in the Montgat-Mataró motorway was undertaken three years after the PVR exceeded the accumulated investment and two after this was achieved by the PVNR. In the case of the Barcelona-La Jonquera the time gap is even longer (from 1990 to 1998). Therefore, the key comparison we want to highlight is the one between fixed and variable term mechanisms. This being said, it is also interesting to point out that the using of flexible term mechanisms would have avoided both renegotiations, if we consider that the profit margin obtained by 
ACESA until 1990 in the Montgat-Mataró and until 1998 in the Barcelona-La Jonquera was high enough under a variable term concession scheme.

\section{$<<$ Insert Figures 2-3 about here $>>$}

Since we are not changing the toll setting undertaken during the period studied, the main reason that explains this reduction is the dramatic evolution of traffic enjoyed by the concessionaire. In fact, the Average Daily Traffic (ADT) received by the Montgat-Mataro motorway was 10.393 vehicles in 1970, while in 1989 this ADT increased to 31.234. In the case of Barcelona-La Jonquera its ADT was 12.903 in 1976, year in which the whole motorway was finally constructed, while in 1991 reached the level of 27.801 vehicles. On the contrary, the average ADT for the whole toll motorways sector in Spain rose from 10.541 vehicles in 1976 to 13.999 in 1991 . Thus, this increase received by the routes studied was much higher than the one experienced for the whole sector in Spain for the same period. While the demand of these motorways at the beginning of the nineties was two or even three times the demand enjoyed at the beginning of the concession, the ADT enjoyed for the whole sector did not significantly grow.

As a result, we can show that with flexible term concession contracts we can avoid extraordinary profit margins derived from unexpected traffic increases. To justify this, we compute the accumulated level of PVR and PVNR of 1967 obtained by ACESA until 2000. As table 4 shows, we find that the PVNR, which is the most conservative, was more than two times the 1990's accumulated investment in the Barcelona-La Jonquera motorway (375 million euro). ${ }^{10}$ It means a huge profit margin based on the collection of more than

${ }^{10}$ It is not possible to compute the same PVR for the Montgat-Mataró motorway because in 1990 the concessionaire agreed with the government a route extension that supposed a huge investment and a different length of the motorway that do not allow to compare both situations as we do in the Barcelona-La Jonquera toll motorway. 
1.069 million euro paid by the users between 1991 and 2000 that could be limited thanks to variable term mechanisms as we have checked above.

\section{$<<$ Insert Table 4 about here $>>$}

Therefore, these cases exemplify one of the problems derived from the establishment of a fixed length of concession. When unexpected increases of traffic appear, the firm obtains enormous profits during a continuous period of time affecting the public acceptance of the concession system and debilitating the role played by the regulation implemented by the government.

To sum up, the case study considered is a clear example of unexpected demand increases that are finally translated into user overpayments, too much private profits and as a result, a weaker acceptance of the public policy applied.

\section{CONCLUDING REMARKS.}

The growing participation of the private sector in toll motorways implies a renewed interest for regulation and for the nature of the public intervention. In fact, worldwide experiences show perverse outcomes that can be summarized in generalized renegotiations, huge public resources transferred to private firms and the establishment of favourable guarantees. In the end, these drawbacks affect the welfare of the users because they were finally assuming the traffic risk of the business incurring in overpayments or just getting damaged as taxpayers. Solving these pitfalls and assuring the best outcome from the private participation means a new and an encouraging challenge for policy makers.

Recent theoretical developments and the accurate study of some experiences assert that the rigidity of the contractual framework, in particular the fixed term of concession 
usually awarded, is found as the main cause of most of the problems aforementioned and suffered in infrastructure projects with huge sunk costs and uncertain demands.

The literature offers two alternative mechanisms of concession based on variable term solutions in order to avoid these drawbacks. The Least Present Value of Revenues (Engel, Fisher and Galetovic, 1997) and the Least Present Value of Net Revenues (De Rus and Nombela, 2004) rely on the idea that traffic risk must be internalized in the contractual framework, letting the length of the contract to be adapted depending on the traffic actually received. This means that routes with lower demands than expected would rest under concession for a longer period until the concessionaire obtains a specific present value of revenues amount. On the contrary, when the motorway lives an unexpected traffic increase, the period of concession becomes shorter.

Since these mechanisms enjoy little impact in the real world and the scarce experiences that chose variable term contracts do not allow for a real comparison yet, we used real data from the two oldest Spanish toll motorways to compare the implementation of fixed and flexible term models. The simulation relies on the construction of a contra factual to check the performance of LPVR and LPVNR methods in those motorways. Since we had available data for toll revenues and accumulated investment for each route, it was possible to compute and determine the year in which the concession would have ended with both variable term models.

Our results show that the implementation of variable term contracts would have dramatically reduced the concession period and consequently, the user's overpayment and the company's profits. Since the routes studied suffered an unexpected and spectacular traffic increase, much higher than the one experienced by the whole Spanish toll motorways sector, it makes sense to find short concession periods between 19 and 25 years instead of the 37 years established in the initial contract. 
Therefore, variable term models mitigate traffic risks and as a result, are powerful tools to improve the social welfare. Furthermore, they are also able to reinforce the public acceptance and support enjoyed by the regulation applied by the government.

Variable term models have been well established from a theoretical point of view, although its use in practice has been scarce insofar. Gathering and analyzing empirical evidence on the practical working of these models can help to increase its using in publicprivate partnerships. 


\section{References}

Albalate, D., Bel, G. and X. Fageda. 2007. "Privatization and Regulation of Toll Motorways in Europe.” Research Institute of Applied Economics Working Paper 04/2007.

Bel, G. 1999. "Financiación de infraestructuras viarias: la economía política de los peajes." Papeles de Economía Española, 0 (82), pp 123-139.

Bel, G. and X. Fageda. 2005. "Is a mixed funding model for the highway network sustainable over time? The Spanish case". in Ragazzi, G and W. Rothengatter (eds.), Procurement and Financing of Motorways in Europe. Elsevier, pp 195-211.

Bel, G. and J. Foote. 2007. Comparison of Recent Toll Road Concession Transactions in the United States and Europe. Working paper, Universitat de Barcelona \& Harvard University.

Burris, M. 2006. "Incorporating variable toll rates in transportation planning models". International Journal of Transport Economics, 33(3), pp 351-368.

Capen, E.C., Clapp, R. V. and W.M. Campbell. 1971. "Competitive bidding in high-risk situations," Journal of Petroleum Technology, 23, pp. 641-653.

De Palma, A., Kilani, M. and R. Lindsey. (2005) "Congestion pricing on a road network: A study using the dynamic equilibrium simulator METROPOLIS" Transportation Research: Part A. 39, pp 588-611.

De Rus, G. Romero, L. and M. Trujillo. 2000. Participación privada en la construcción y explotación de carreteras de peaje. Documento de trabajo, 159. Fundación Fondo para la Investigación Económica y Social. FIES (Madrid, Spain).

De Rus, G. and M. Romero. 2004. "Private financing of roads and optimal pricing: Is it posible to get both?" The Annals of Regional Science, 38 (3), pp 485-497.

De Rus, G. and G. Nombela. 2004. "Flexible-term contracts for road franchising" Transportation Research Part A 38, pp 163-179.

Engel, E., Fischer, R. and A. Galetovic. 1996. "Licitación de carreteras en Chile". Estudios Públicos, 61, pp 5-37.

Engel, E., Fischer, R. and A. Galetovic. 1997. "Highway Franchising: Pitfalls and Opportunities". American Economic Review, Papers and Proceedings, 87 (2), 68-72.

Engel, E., Fischer, R. and A. Galetovic. 2001. "Least-Present-Value-of-Revenue Auctions and Highway Franchising". Journal of Political Economy, 109 (5), pp 993-1020.

Engel, E., Fischer, R. and A. Galetovic. 2002. "A New Approach to Private Roads" Regulation, 25 (3) Fall, pp 18-22.

Engel, E., Fischer, R. and A. Galetovic. 2003. "Privatizing Highways in Latin America: Is it possible to fix what went wrong?", The Journal of the Latin American and Caribbean Economics Association (LACEA), 4 (1), pp 129-158.. 
Estache, A. and G. De Rus. 2000. Privatization and Regulation of Transport Infrastructure: Guidelines for Policymakers and Regulators. Washington, D.C.: The World Bank.

Foice, D. 1998. "Second Severn Crossing”, Proceedings of the Seminar PPP Risk. Managementfor Big Transport Projects, Ministerio de Fomento, Spain.

Fisher, G. and S. Babbar. 1996. "Private financing of Toll Roads" RMC Discussion Paper Series 117. Project Finance and Guarantees Group. The World Bank.

Gómez-Ibáñez, J.A. and J.R. Meyer. 1993. Going Private: The international Experience with Transport Privatization. The Brookings institution, Washington DC.

Góme-Lobo, A. and S. Hinojosa. 2000. Broad Roads in a Thin Country: Infrastructure concessions in Chile, Research paper 2279, The World Bank, Washington DC.

Guasch, J. 2004. Granting and Renegotiating Infrastructure Concessions: Doing it right. The World Bank Institute Development Studies, Washington DC.

Lemus, T., Eaton, D. Betts, and L.T. de Almeida. 2004. "Risk management in the Lusoponte Concession - a Case Study of the Two Bridges in Lisbon, Portugal." International Journal of Project Management, 22, pp 63-73.

Nakamura, K. and K. Kockelman. 2002. "Congestion pricing and roadspace rationing: an application to the San Francisco Bay bridge corridor". Transportation Research Part A, 36 (5), pp 403-417.

Pigou, A. 1920. Wealth and Welfare. Macmillan, London.

Puncel, A. 1996. La autopista del Mediterráneo. Servicio de Publicaciones de la Universidad de Valencia. Valencia, Spain.

Robinson, J. and R. Torvik 2005. "White elephants" Journal of Public Economics, 89, pp 197210.

Ruster, J. 1997. "A Retrospective on the Mexican toll program (1989-1994)" Public Policy for the Private Sector, 25. The World Bank, Washington DC.

Tirole, J. 1997. "Comentario a la propuesta de Engel, Fischer and Galetovic sobre licitación de carreteras.” Estudios Públicos 65 Winter, pp 201-214.

Vasallo, J. 2006. "Traffic Risk Mitigation in Highway Concession Projects" Journal of Transport Economics and Policy, 40 (3), pp 359-381.

Vickrey, W. 1969. "Congestion theory and transport investment". American Economic Review, Papers and Proceedings, 59, 251-260.

Walters, A. 1968. The economics of road user charges. The Johns Hopkins Press, Baltimore, Maryland. 


\section{TABLES and FIGURES}

Table 1: Term determined by awarding mechanism. Montgat-Mataró.

\begin{tabular}{|c|c|c|c|c|c|c|c|}
\hline Montgat-Mataró & & & & $\begin{array}{c}\text { Barcelona- } \\
\text { La Jonquera }\end{array}$ & & & \\
& $\mathrm{r}=0.04$ & $\mathrm{r}=0.05$ & $\mathrm{r}=0.06$ & & $\mathrm{r}=0.04$ & $\mathrm{r}=0.05$ & $\mathrm{r}=0.06$ \\
\hline LVPR & 19 & 20 & 21 & LPVR & 20 & 21 & 23 \\
\hline LVPNR & 20 & 21 & 23 & LPVNR & 22 & 23 & 25 \\
\hline Fixed in 1969 & 37 & 37 & 37 & Fixed in 1967 & 37 & 37 & 37 \\
\hline
\end{tabular}

Table 2: Accumulated investment and PVR/PVNR by discounting rate. Montgat-Mataró. (Thousands Euro).

\begin{tabular}{|c|c|c|c|c|c|c|c|}
\hline Year & Investment & $\begin{array}{c}\text { PVR } \\
\mathrm{r}=\mathbf{0 . 0 4}\end{array}$ & $\begin{array}{c}\text { PVR } \\
\mathrm{r}=\mathbf{0 . 0 5}\end{array}$ & $\begin{array}{c}\text { PVR } \\
\mathrm{r}=\mathbf{0 . 0 6}\end{array}$ & $\begin{array}{c}\text { PVNR } \\
\mathrm{r}=\mathbf{0 . 0 4}\end{array}$ & $\begin{array}{c}\text { PVNR } \\
\mathrm{r}=\mathbf{0 . 0 5}\end{array}$ & $\begin{array}{c}\text { PVNR } \\
\mathrm{r}=\mathbf{0 . 0 6}\end{array}$ \\
\hline 1986 & 23,079 & 25,327 & 22,255 & $\mathbf{1 9 , 6 2 3}$ & 20,260 & $\mathbf{1 7 , 8 0 8}$ & $\mathbf{1 5 , 6 9 8}$ \\
\hline 1987 & 23,115 & - & 25,501 & 22,304 & 23,403 & 20,298 & 17,844 \\
\hline 1988 & 23,145 & - & - & 25,315 & - & 23,337 & 20,248 \\
\hline 1989 & 23,367 & - & - & - & - & - & 22,959 \\
\hline 1990 & $23,367 *$ & - & - & - & - & - & 25,946 \\
\hline
\end{tabular}

Source: Author's, using data contained in the economic yearbooks of ACESA 1967-2000. *Data not available. We used the previous year accumulated investment because this is a variable that does not vary significantly from one year to another. Moreover, the project of enlargement started in 1991.

Table 3: Accumulated investment and PVR/PVNR by discounting rate. Barcelona-La Jonquera. (Thousands Euro).

\begin{tabular}{|c|c|c|c|c|c|c|c|}
\hline Year & Investment & $\begin{array}{c}\text { PVR } \\
\mathbf{r}=0.04\end{array}$ & $\begin{array}{c}\text { PVR } \\
\mathbf{r}=\mathbf{0 . 0 5}\end{array}$ & $\begin{array}{c}\text { PVR } \\
\mathbf{r}=\mathbf{0 . 0 6}\end{array}$ & $\begin{array}{c}\text { PVNR } \\
\mathbf{r}=0.04\end{array}$ & $\begin{array}{c}\text { PVNR } \\
\mathbf{r}=\mathbf{0 . 0 5}\end{array}$ & $\begin{array}{c}\text { PVNR } \\
\mathbf{r}=\mathbf{0 . 0 6}\end{array}$ \\
\hline 1986 & 152,176 & 141,947 & $\mathbf{1 2 3 , 9 2 3}$ & $\mathbf{1 0 8 , 4 8 3}$ & $\mathbf{1 1 3 , 5 6 1}$ & $\mathbf{9 9 , 1 3 7}$ & $\mathbf{8 6 , 7 8 6}$ \\
\hline 1987 & 152,982 & 163,776 & 141,947 & 123,394 & 131,027 & 113,561 & $\mathbf{9 8 , 7 1 6}$ \\
\hline 1988 & 157,718 & - & 161,853 & 139,705 & 150,493 & 129,482 & 111,764 \\
\hline 1989 & 161,221 & - & - & 157,068 & 171,607 & 146,587 & 125,654 \\
\hline 1990 & $161,221^{*}$ & - & - & 175,826 & - & 165,254 & 140,661 \\
\hline 1991 & $161,221^{*}$ & - & - & - & - & - & 156,377 \\
\hline 1992 & $161,221^{*}$ & - & - & - & - & - & 172,815 \\
\hline
\end{tabular}

Source: Author's, using data contained in the economic yearbooks of ACESA 1967-2000.

*Data not available. We used the previous year accumulated investment because this is a variable that does not vary significantly from. Moreover, no project of enlargement started in that route during this period. 
Table 4: Toll Revenue and accumulated PVR/PVNR by time interval in the Barcelona-La Jonquera. (Thousands Euro).

\begin{tabular}{|c|c|c|c|c|c|}
\hline $\begin{array}{c}\text { Time } \\
\text { Interval }\end{array}$ & $\begin{array}{c}\text { Toll } \\
\text { Revenues }\end{array}$ & $\begin{array}{c}\text { Accumulated } \\
\text { PVR }\end{array}$ & $\begin{array}{c}\text { Time } \\
\text { Interval }\end{array}$ & $\begin{array}{c}\text { Toll } \\
\text { Revenues }\end{array}$ & $\begin{array}{c}\text { Accumulated } \\
\text { PVNR }\end{array}$ \\
\hline $1967-2000$ & $1,557,980$ & 468,940 & $1967-2000$ & $1,557,980$ & 375,158 \\
\hline $1967-1988$ & 354,669 & 161,853 & $1967-1990$ & 488,875 & 165,254 \\
\hline $1989-2000$ & $1,203,310$ & 307,087 & $1991-2000$ & $1,069,104$ & 209,903 \\
\hline
\end{tabular}

Figure 1: Choices for changes in concessions

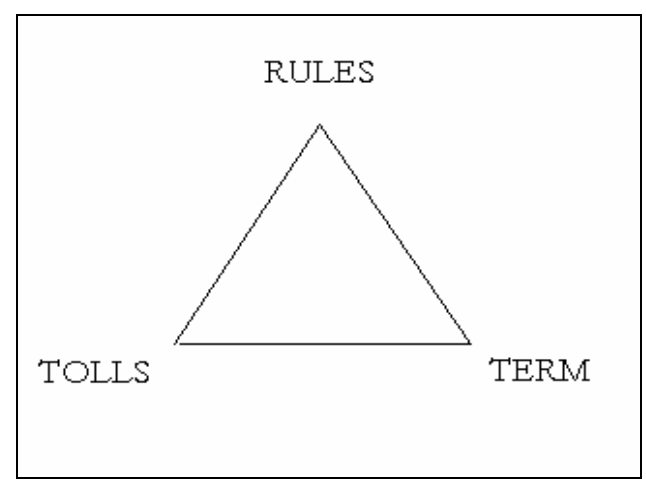

Figure 2: Concession Terms by LPVR (Montgat-Mataró).

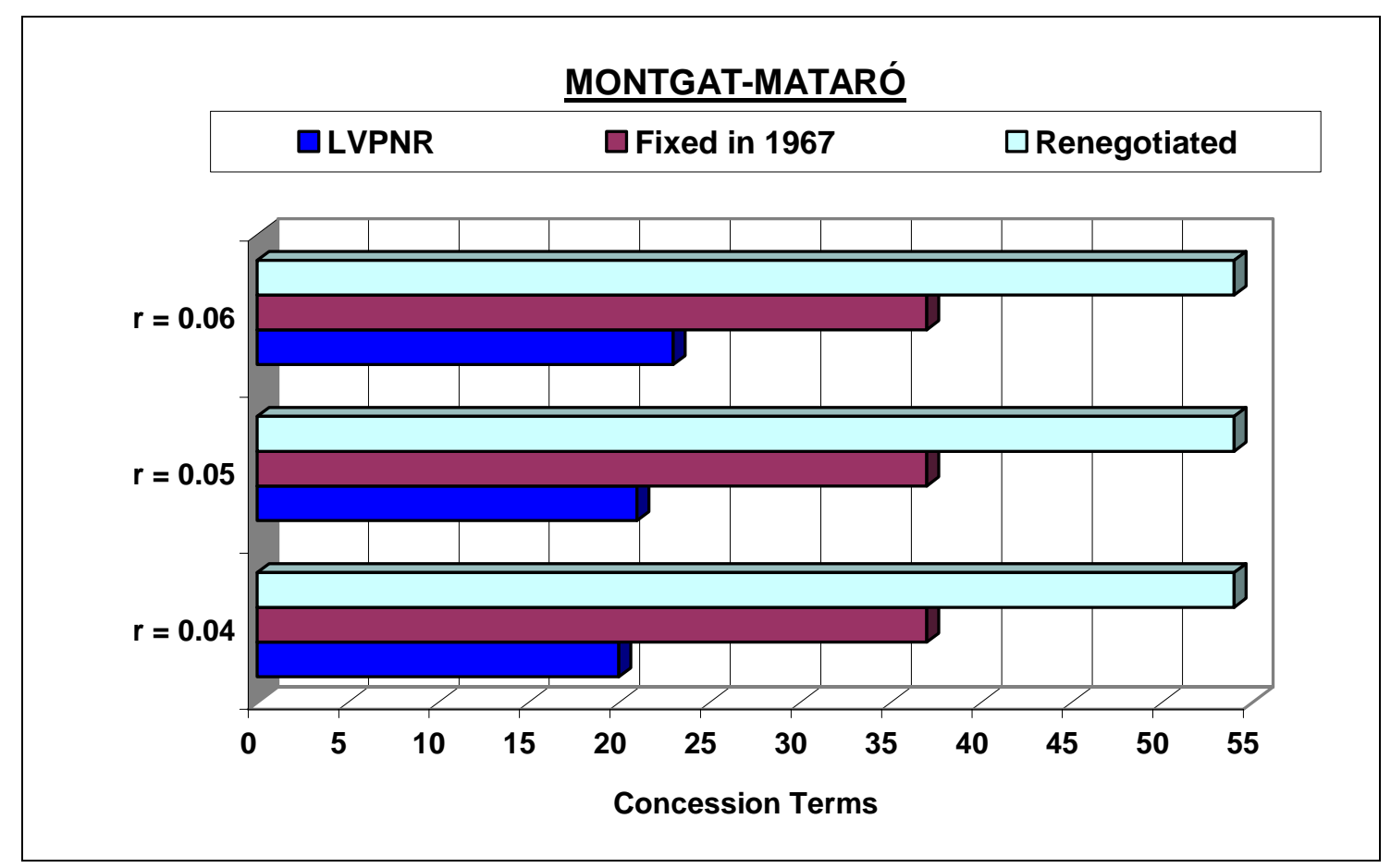


Figure 3: Concession Terms by LPVNR (Barcelona-La Jonquera).

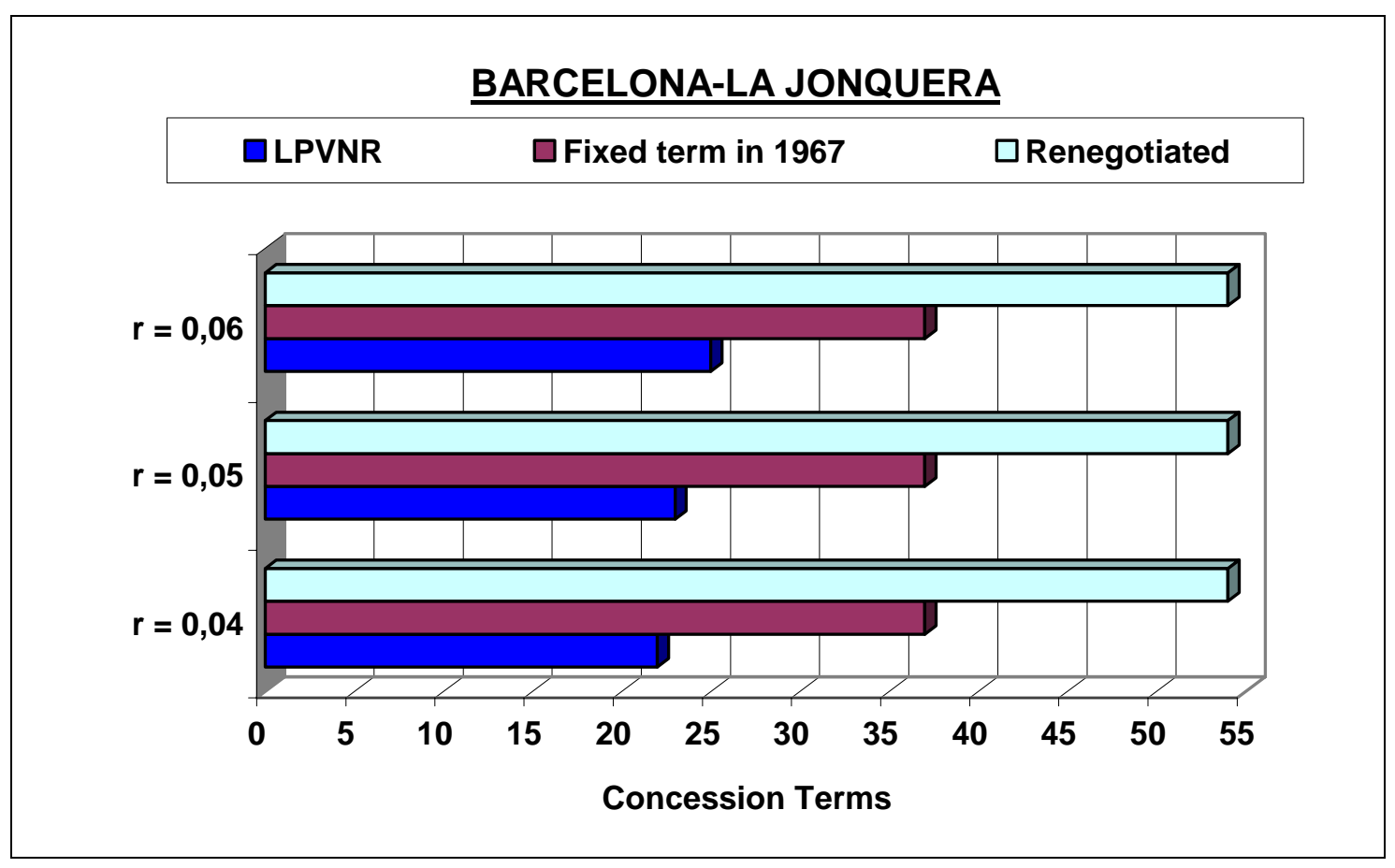

